\title{
WORKING RULES FOR ASSURING NONDISCRIMINATION IN HOSPITAL ADMINISTRATION
}

IN recent years a few state courts ${ }^{1}$ and legislatures ${ }^{2}$ have become increasingly aware of the potentialities for unfairness and discrimination inherent in the broad powers of self-regulation enjoyed by the American medical profession $^{3}$ and its associated voluntary hospitals. ${ }^{4}$ But until the recent Fourth $\mathrm{Cir}$ cuit decision in Simpkins v. Moses H. Cone General Hospital, 5 the only federal court involvement in this area had been peripheral. ${ }^{\circ}$ In Cone, the Fourth Circuit rushed in where, five years before, it had feared to tread, ${ }^{7}$ and proscribed discrimination against Negro doctors, dentists and patients in federally-aided voluntary hospitals. It held that (a) acceptance of state-channelled federal funds for construction brought hospital discrimination within the prohibitions of the fifth and the fourteenth amendments, ${ }^{8}$ and (b) the "separate

1. Greisman v. Newcomb Hosp., 40 N.J. 389, 192 A.2d 817 (1963); Falcone v. Afiddlesex County Medical Society, 34 N.J. 582, 170 A.2d 791 (1961).

2. See, e.g., recent developments in New York indicating a tendency to curb hospital and medical powers of self regulation. These include enactment of a system of "medical audits" to help provide a check on quality of medical care (N.Y. Sess. Laws 1963, ch. 326), limitation upon the numbers of physicians serving on the boards of medical service corporations (N.Y. Sess. Laws 1963, ch. 719), barring of discrimination against physicians by private institutions (N.Y. Sess. Laws 1963, ch. 913) and setting up a system of licensure for chiropractors, allowing them to use $X$-ray equipment and including a "grandfather clause" for the benefit of current practitioners (N.Y. Sess. Laws 1964, ch. 295). This last enactment was a legislative reversal of Chiropractic Ass'n v. Hilleboc, 16 App. Div. $2 d$ 285, 228 N.Y.S.2d 358, aff'd, 12 N.Y.2d 109, 187 N.E.2d 756, 237 N.Y.S.2d 289 (1962), in which the court allowed the Public Health Council of New York; a governmental body dominated by physicians, to effectively bar chiropractors from using $\mathrm{X}$-ray machines, essential to their practice.

3. See Comment, The American Medical Association: Pouer, Purpose and Politics in Organized Medicine, 63 Yale L.J. 938 (1954).

4. See Harrison, Control of Mfedical Staff Appolntarents in Volunitary NonpRofit Hosprtals (Am. Hospital Ass'n 1963). A "voluntary" hospital is one operated on a non-profit basis by a private charitable trust or religious group. It is to be distinguished from "public" (government-owned) hospitals and "proprietary" (private, but operated for profit) hospitals. In 1962, 2276 accredited American hospitals vere classified as voluntary, 524 as public and 154 as proprietary. Id. at 4 .

5. 323 F.2d. 959 (4th Cir. 1963), reversing 211 F. Supp. 628 (1L.D.N.C. 1962), ecrt. denied, 376 U.S. 938 (1964).

6. Federal courts have moved against discrimination against physicians beeause of membership in group health plans. The Gront Health Cases: United States v. Ameriean Medical Ass'n, 28 F. Supp. 752 (D.D.C. 1939), aff'd, 110 F.2d 703 (D.C. Cir.), ccrt. denied, 310 U.S. 644 (1940), conviction on remand upheld, 130 F.2d 233 (D.C. Cir. 1942), aff'd in part, 317 U.S. 519 (1943). In noneconomic contexts, the Federal rule has remained one of nonintervention. Shulman v. Washington Hospital Center, 222 F. Supp. 59 (D.D.C. 1963).

7. Eaton v. Walker Memorial Hosp., 261 F.2d 521 (4th Cir. 1958).

8. 323 F.2d 959, 967. 
but equal" proviso to the non-discrimination clause of the Hospital Survey and Construction Act (the "Hill-Burton Act") and the regulations promulgated thereunder were unconstitutional. ${ }^{2}$ Certiorari was denied. ${ }^{10}$

Of the two holdings, the second, while at first glance more dramatic, ${ }^{11}$ is the less important. It will apply only to future federal expenditures under the Hill-Burton Act; ${ }^{12}$ the Secretary has announced his acquiescence $;{ }^{13}$ and Title VI of the recently passed Civil Rights Act ${ }^{14}$ bars the use of federal funds in situations such as that presented in Cone. The first holding is not only broader

9. Id. at 969-70. The statute provides:

Within six months after August 13,1946 , the Surgeon General . . . shall by general regulation prescribe...

(f) That the State plan shall provide for adequate hospital facilities for the people residing in a State, without discrimination on account of race, creed or color, and shall provide for adequate hospital facilities for persons unable to pay therefor. Such regulation may require that before approval of any application for a hospital or addition to a hospital is recommended by a State agency, assurance shatl be received by the State from the applicant that (1) such hospital or addition to a hospital will be made available to all persons residing in the territorial area of the applicant, without discrimniation on account of race, creed, or color, but an cxccption shall be made in cases where separate hospital facilities are provided for separate population groups, if the plan makes equitable provision on the basis of need for facilities and services of like quality for each such graup; and (2) there will be made available in each such hospital or addition to a hospital a reasonable volume of hospital services to persons unable to pay therefor, but an exception shall be made if such a requirement is not feasible from a financial standpoint.

60 Stat. 1042 (1946), 42 U.S.C. $\$ 291$ e (1958) (emphasis supplied). Only the italicizcd language was held unconstitutional. The regulations contain a similar non-discrimination provision followed by a proviso allowing its waiver if (a) the state agency finds "equitable provision on the basis of need" for the excluded group and (b) the finding is approved by the Surgeon General. 42 C.F.R. \& 53.112 (1960). "Relevant regulations" - presumably meaning the proviso - were said by the court to fall within the unconstitutional portion of the statute. 323 F.2d at 969-70.

10. 376 U.S. 938 (1964).

11. The United States, intervening, had urged "unusually enough" the unconstitutionality of the statute and regulations. 323 F.2d 959, 962.

12. The Surgeon General's power to apply sanctions for noncompliance with $\S 291 \mathrm{e}(\mathrm{f})$ regulations is limited to withholding certification of further fund requests for any project or projects designated by him as affected by the default. 60 Stat. 1047 (1946), 42 U.S.C. $\$ 291(j)$ (1958). Once Federal funds are paid, they may be recovered only if the hospital is converted to proprietary operation. 60 Stat. 1046 (1946), 42 U.S.C. $\$ 291 \mathrm{~h}(\mathrm{e})$ (1958).

13. Testimony of Anthony J. Celebrezze, Secretary of Health, Education and Welfarc before the House Committee on Interstate and Foreign Commerce, reported in the New York Times, Mar. 10, 1964, p. 20, cols. 1, 2. Indeed, if "assurances of non-discrimination, applying to patients, staff privileges and admissions, will be required in all hospital projects built with Federal aid," ibid., the Federal government is going somewhat beyond the limits in the first Cone holding, for the general non-discrimination provision of $\$ 201 \mathrm{c}$ (f) seems to apply only to patients. See note 9 sipra.

14. Title VI, $\S 601$, The Civil Rights Act of 1964, 78 Stat. 241 (1964). Perhaps the denial of certiorari can be traced to the pendency of this measure. Previous similar legislative proposals had received the support of the American Hospital Association. Hospitals, Sept. 16, 1963, p. 95. 
than the second, ${ }^{15}$ but also lays the doctrinal underpinnings for an exercise of judicial control over internal hospital affairs far more sweeping than any previously attempted. ${ }^{16}$ In establishing a right to relief for excluded Negro physicians, dentists and patients, the court not only effectively overruled prior decisions permitting such discrimination against Negroes, ${ }^{17}$ but also enunciated a rule which seems to proscribe any discrimination based on race, religion or national origin 18 in any area of hospital activity. 19

15. It is retrospective in barring discrimination in any hospital which has accepted Federal funds; it clearly bars discrimination in any facility of such a hospital, while $\$ 291$ (f) seems to bar it only in the facility constructed with federal aid; finally, not only does the holding apply by its terms to doctors, patients and dentists, but there is no reason to suppose its reasoning should not equally apply to all hospital employees.

16. Voluntary hospital staff selection has been generally regarded as private action susceptible to judicial review only when either (a) it becomes involved with the public interest and the hospital officials abuse their discretion, see cases cited in note 1 sispra, or (b) when it is a statutory or common-law crime. See The Group Health Cases, note 6 supra. In general, courts have been very reluctant to find public interest or involvement. See, e.g., Edson v. Griffin Hosp., 21 Conn. Supp. 55 (Super. Ct. 1958); Straus v. Mlarlboro County General Hosp., 185 S.C. 425, 194 S.E. 65 (1937). Without such involvement, even seemingly arbitrary staff expulsion has no remedy. Hughes v. Good Samaritan Hosp., $289 \mathrm{Ky} .123$, 158 S.W.2d 159 (1942); State ex rel. Wolf v. LaCrosse Lutheran Hosp. Ass'n, 181 Wis. 33, 193 N.W.2d 994 (1923) [citing Anonymous' Case, 90 Eng. Rep. 331 (K.B. 1687)]. For an unsuccessful attempt to apply civil anti-trust sanctions, see United States v. Oregon State Medical Soc'y, 343 U.S. 326 (1952). Even in the case of publicly-owned hospitals, although there are some cases to the contrary [e.g., Wyatt v. Tahoe Forest Hosp. Dist., 174 Cal. App. 2d 709, 345 P.2d 93 (1959)], courts gencrally have declined to review staff appointments because they fall within staff discretion unless appointments or exclusions are "arbitrary." See, e.g., Dayan v. Wood River Tounship Hosp., 18 Ill. App. 2d 263 (1958); Dade County v. Trombly, 102 So. 2d 394 (Fla. Dist. Ct. App. 1958); Green v. City of St. Petersburg, 154 Fla. 339, 17 So. $2 d 517$ (1944); Selden v. City of Sterling, 316 Ill. App. 455 (1942).

Since, however, the first Cone holding makes hospital practices "state action" in the sense that the phrase is applied in Burton v. Wilmington Parking Authority, 365 U.S. 715 (1961), the court need not apply these threshold tests of jurisdiction; instead, it can proscribe directly any hospital staff exclusion as contrary to the fourteenth amendment.

17. Apparently the only previous federal cases directly involving exclusion of Negroes are those involving James Walker Memorial Hospital. Admission was denied. Eaton v. Walker Memorial Hosp., 164 F. Supp. 191 (E.D.N.C. 1958), aff'd, 261 F.2d 521 (4th Cir. 1958). Relitigation following Burton v. Wilmington Parking Authority was unsuccessful. Eaton v. Grubbs, 216 F. Supp. 465 (E.D.N.C. 1963), despite a Fifth Circuit dictum that the previous case had been overruled sub silentio by Burton. Hampton v. City of Jacksonville, 304 F.2d 320 (5th Cir. 1962). Apparently the only state court case involving exclusion of Negroes in a medical context is Hillary v. Pedic Soc'y, 189 App. Div. 766, 129 N.Y.S. 62 (1919) (expulsion of Negro from "Pedic Society" held procedurally improper). However, state and federal rules sanctioning broad hospital discretion in excluding anyone (see note 16 sapra) certainly also apply to Negroes.

18. This case of course raises problems in regard to denominationally owned and operated voluntary hospitals. An attempt to proscribe religious discrimination by such institutions might run head-on into a first amendment freedom of religion argument. However, this Note does not attempt to deal with such issues, confining itself instead to discrimination, chiefly against Negroes, practiced by non-religious voluntary hospitals.

19. By the terms of the decision the hospital is unable to make any classification or distinction which would be improperly made by the state which acts through it, and any 
A court faced with the task of enforcing this mandate will be compelled to examine complex areas of internal hospital activity into which the courts have never before closely inquired. While a court should have relatively little difficulty mastering the intricacies of hospital administrative machinery, it may face substantially greater problems in deciding cases in which a differentiation is defended on the ground that it is medically necessary, either because it is an element of the most prudent course of treatment for a given patient, or because it is essential to the maintenance of the quality of medical care available to all patients. There is little doubt that such considerations will be involsed to justify hospital policies in Cone-type enforcement cases; they have been the constant theme of hospital spokesmen in other situations - such as labor disputes $^{20}$ - in which attempts have been made to exert external control over internal hospital policies. It seems equally certain that a court which acted to bar hospital discrimination without keeping such considerations in mind might run the risk of inadvertently lowering the quality of medical care. Of course, a policy of non-discrimination is in itself in no way inconsistent with high medical standards; indeed it should work to raise them substantially. The danger, however, lies in the potential lowering of care standards that might result from an uninformed attempt to summarily order non-discrimination, or alternatively, in the possibility of judicial inaction which might be encouraged by vigorous hospital arguments that any change would detrimentally affect the quality of care. ${ }^{21}$ The maintenance of care standards is a social goal given great value in our society, however irrationally this value is purstted, ${ }^{22}$ and the court enforcing non-discrimination should therefore undertake to do so in

classification, in any area of state behavior made on the basis of race, religion or national origin is, barring unusual circumstances, [cf. Korematsu v. United States, 323 U.S. 214 (1944) ] improper.

20. See, e.g., The Modern Hospital, June 1959, pp. 63-64. Moreover, courts have been receptive to this argument. See, e.g., Society of New York Hosp. v. Hanson, 185 Misc. 937, 943, 59 N.Y.S.2d 91, 96 (1945), aff'd, 272 App. Div. 998, 73 N.Y.S.2d 835 (1947).

21. Quality would surely be affected if a court, finding racial exclusion, were to order a hospital staff to accept chiropractors. See New York Times, Mar. 26, 1964, p. 16, col. 7. See also text accompanying notes 50-53 infra.

22. American hospitals alone were said to employ $1,840,000$ workers in 1963 , as compared to 830,000 in 1946. Hospitals, Aug. 1, 1962, p. 482. In addition, many more are cmployed in the supplying of drugs, hospital supplies and other ancillary medical needs. Total hospital expenditures for 1963 were $\$ 10,956,000,000$. Ibid. Total annual expenditures for medical care in the United States have been estimated to be 33 billion dollars. Hannrs, The Economics of Amrerican Medicine (1964). In spite of the resources expended for medical care, it could be argued that the quality of care is not so important a value that it should ever be balanced against 14th amendment rights of Negro citizens. The impor tance given care standards, an importance which allows them to take precedence over such established values as enlightened labor policy (see note 20 sitpra) seems strange when it is considered that the reason for maintaining high care standards is the preservation of human life and health and this in turn is a value which is compromised in favor of such values as convenience (in allowing operation of private automobiles at high specds) and economic benefit to private persons (in allowing continued widespread use of cigarettes). 
a manner which has the least deleterious effect on those standards. 23 Such a court, then, faced with the argument that an allegedly discriminatory practice is necessary to protect care quality, should (a) determine whether the argument is mere sham and (b) if it is not, devise a mode of enforcement which does not endanger the quality of care. ${ }^{24}$

The four areas of voluntary hospital activity in which discriminatory practices are likely to arise are education and training programs, employment, patient admission and treatment, and medical and professional staff appointment. Clearly, no substantial argument can be made to justify the exclusion of academically qualified minority group applicants 25 from admission to hospital schools and training courses for nursing, laboratory technology and other "health" professions on the basis of protection of standards of care. ${ }^{23}$ Nor can any more than de minimis defenses for discrimination in hiring of unskilled or skilled hospital employees be raised on the basis of maintaining care quality. ${ }^{27}$ Consequently, a court faced with such arguments should not hesitate in ordering an end to discrimination. Similarly unjustifiable on medical grounds is a policy which, like that of the Moses H. Cone General Hospital, ${ }^{28}$ calls for

23. The court should, however, keep in mind that even if a policy of non-discrimination is enforced in a manner which, because of some of the factors discussed in this Note, inadvertently results in a reduction in the quality of care in a hospital such as that in Cone, the overall level of medical care in the community would still probably rise substantially. Whatever the level of care at Mloses $\mathrm{H}$. Cone General Hospital would be after the most hastily-conceived desegregation order, it would almost surely be higher than that previously provided for excluded Negro citizens, whose infant mortality rate is twice that of white residents of North Carolina, and whose maternal death rate is five times that of

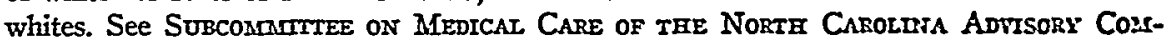
aittree to the Untred States Comantssion on Cintl Rrghts, Eouar. Protectios of the Laws Concerning Medical Care in North Caroltna, Appendix $K$. (Cited in the Cone case at 323 F.2d 970 n.23). It could be argued that, whatever the lowering effect on Cone Hospital care standards, summary admission of Negro physicians and their patients would be justified by a corresponding increase in the overall standard of care.

24. This Note does not undertake to deal with the difficult evidentiary problems that arise in proving a case that racial discrimination exists in a hospital - it is instead concerned with dealing with defenses which may be raised once such a showing has been made.

25. This Note does not deal with exclusion of non-Catholies from schools and training courses run by Catholic hospitals. See note 18 supra. Nor does it attack the problem presented by non-discriminatory application of academic qualifications, which do in fact discriminate against Negroes, because of their previous educational deprivation.

26. Probably the only argument which could be offered would be one going to the morale or mental condition of patients cared for by nurses or student nurses who are members of a minority group the patients hate or fear. Such an argument must be dismissed as de minimis. See text accompanying notes 36-38 infra. Since hospital training programs are often supervised, or even supported by state educational departments, they are subject to desegregation under Brown v. Board of Educ, 347 U.S. 483 (1954), as well as under Cone.

27. Or, of course, professional persons, such as nurses, pathologists and chemists, who are employees of the hospital.

28. 323 F.2d $959,962$. 
the turning away of patients simply because they are members of minority groups. Absent a showing that the hospital was full ${ }^{20}$ or unequipped to deal with the patient's condition ${ }^{30}$ or that valid medical judgment had counseled an exclusionary policy applied without regard to race, religion or national origin, ${ }^{31}$ a court should again not hesitate in ordering a hospital to admit minority-group patients. ${ }^{32}$

29. Immediate admission to a hospital is seldom gained by a patient who does not require emergency treatment or surgery or who is not in labor. For surgical procedures or courses of treatment which are "elective" (i.e. which need not be done immediately) the waiting period for admission in most hospitals is six to twelve weeks.

30. A hospital specializing in the treatment of a specified disease, such as tuberculosis, could legitimately refuse to admit an appendicitis patient; similarly a general hospital could decline to treat a tubercular patient if it had no facilities for isolating him from other patients.

31. One example of such a practice would be the policy, widely followed before development of poliomyelitis vaccines, of closing all pediatric wards and services to nonemergency patients during summer months.

32. Unfortunately, if the patient is not admitted to the hospital following such order on the grounds that he cannot pay the bill, there is nothing, under the mandate of Conc, that the court can do about it. Few hospitals still provide the free charity service that was the original purpose of American hospitals. Belknap \& Steinle, The Community and ITs Hosprials 9 (1963). As mounting costs have made the performance of this charity function impossible, some voluntary hospitals have concluded arrangements with government welfare services to provide emergency services and treatment of the indigent patients, while others have simply ceased to provide these services entirely. Voluntary hospitals have been categorized as economically "unrestricted" (providing such services) and cconomically "restricted" (not providing them). Id. at 30-35. While the financial position of the economically unrestricted hospital is likely to be somewhat precarious (id. at 16), the economically restricted hospital often shows a substantial surplus, which is seldom used to reduce costs to the patient, but is instead salted away in "reserve" accounts. Id. at 29. Economic discrimination is clearly practiced against patients in at least some cconomically restricted hospitals (id. at 41), and since Negroes are often in the low-income group (id. at 86), there seems little doubt such practices could be followed for racial reasons, by a hospital eager to avoid the effect of Cone. Indeed, Negroes seem to be experiencing already some such "economic" discrimination, even in the North. See Integration: What Is Hospifal's Role, Hospitals, Oct. 16, 1963, p. 17. Not only does Cone not deal with this problem, but it allows to stand a portion of the act which aggravates it. One of the indices used for allocation of funds under the act is the "support rate" of a hospital - the amount of money made available to the hospital per patient admitted. BELINAP \& STETNLE, op. cit. supra at 51. This rate is higher in economically restricted hospitals because they simply refuse to admit patients who cannot pay. The act thus cncourages hospitals to become economically restricted. Since there seems every likelihood that economically restrictive hospital practices may be used to keep out Negroes, a court might, were a case presented, go beyond Cone, and declare unconstitutional under the fifth and fourteenth amendments, the second proviso to $\$ 291 \mathrm{e}(\mathrm{f})$ of the act, which allows a hospital to follow economically restrictive policies if it shows that it is "not feasible from a financial standpoint" to follow its statutory duty to "provide . . . adequate hospital facilities for persons unable to pay therefor." 60 Stat. 1043 (1946), 42 U.S.C. § 291c(f) (1958). Such a holding would share the limitations of the second Cone holding (sce note 12 supra), however, applying only prospectively and only to the particular facility built with federal aid. For these reasons, legislation is probably the only means of preventing wide- 
Once such a patient has been admitted, discriminatory practices do not necessarily come to an end. He may be given qualitatively inferior medical care ${ }^{33}$ or, more likely, while receiving care as good as that of his non-minority fellow, be subjected to what might be called administrative discrimination segregation by room, ward or the affixing of some distinctive badge of inferiority. ${ }^{34}$ Attempt may be made to justify administrative discrimination as essential to the therapy of a given patient or class of patients. Such an argument would probably take one of two forms. The first would be a contention that labeling members of a racial or minority group is justifiable because differing physical characteristics of the group affect the medical treatment of its members. This argument is unpersuasive; although there are a few medically significant differences between races which might occasionally be central to the treatment of the patient, ${ }^{35}$ the ease with which the physician can ascertain the patient's race makes any racial "labeling" of patients unnecessary. ${ }^{30} \mathrm{~A}$ second argument might be that attitudes of patients make some kind of internal hospital segregation necessary - the ill-feeling between the races being such that sharing of rooms and facilities would create an atmosphere of resentment or tension adverse to the progress of therapy, or might even result in violence. ${ }^{37}$ It is true that tension and resentment might retard a patient's recovery to some extent. Such factors, however, do not generally seem to be considered of great importance in hospital treatment; little is done to assuage similar feelings caused by patients' sudden subjection to other features of the hospital environment. ${ }^{38}$ Moreover, even hospitalized Americans must accommodate themselves to the fourteenth amendment. The patient might equally resent

spread discrimination against Negroes by hospitals which choose to become economically restricted.

33. The possibility that this particular kind of discrimination will be practiced systematically - in the manner that Negro Americans have been systematically denied justice before the law in parts of the United States - seems unlikely. If conscious administration of poor quality medical care to a Negro patient takes place, it is far more probable that it will result from the irresponsibility of an individual physician or hospital employee. Such cases, it may be suggested, are seldom likely to come before the courts.

34. As for instance, requiring Negro persons to list their race on an admission blank, or alloting Negro or other minority group patients a particular color of chart. Requesting religious minority members to list their religion can, of course, be justified on the grounds that such listing is for the purpose of notifying the hospital chaplain of that religion or of respecting dietary preferences.

35. The blood condition, sickle-cell anemia, for instance, apparently occurs only in Negroes or persons of Negro ancestry. See Stedaran's MfedrCal Dictionary 97 (1961).

36. The examining physician, in most cases, should be able to determine the patient's race as easily as he does his sex, and note it upon the patient's medical record.

37. Both arguments have been offered in recent hospital disputes involving racial discrimination. See Integration: What is Hospital's Role, Hospitals, Oct. 18, 1963, p. 19.

38. While some hospitals permit mothers to accompany child patients into the hospital, or allow husbands to remain with their wives during labor (e.g. Grace-New Haven Community Hospital, New Haven, Conn., communication from the Office of Admissions, Mfar. 1, 1964) little seems to be done otherwise to minimize what has been called the "loss of ego identity" experienced by the patient. Coser, LIFE ON THE WARDS 99 (1962). 
sending his children to a desegregated school; his racial sensibilities do not gain constitutional immunity because he is ill. While very unusual medical circumstances ${ }^{39}$ might conceivably justify isolated instances of what is here called administrative discrimination, a court may safely dismiss medical arguments in favor of any general or widespread administratively discriminatory practice in patient treatment.

It is in the fourth area of hospital activity, medical staff membership practices, ${ }^{40}$ that enforcement of a policy of non-discrimination is most likely to inadvertently endanger the quality of medical care. Modern medical treatment requires mechanical, electronic and pharmacological resources ${ }^{41}$ unavailable anywhere except in a hospital. To deny the use of these facilities to a physician is to restrict his practice to simple therapeutic procedures - in effect partially to delicense him. The lot of a physician excluded from the medical staff of the hospital in his area is the unhappy one of being denied the opportunity to give any treatment that cannot be carried out in his office or his patients' homes. And the lot of his patients - should they require major therapy - is to be denied the services of the physician in whom they have reposed their trust. Nor is it generally practical for a group of excluded physicians to start their own hospital. ${ }^{42}$ Negro physicians and patients commonly find themselves in this situation, in northern ${ }^{43}$ as well as in southern ${ }^{44}$ areas of the United States.

Recognizing that hospital exclusion can amount to partial deprivation of the state-granted right ${ }^{45}$ to practice medicine, some courts taking jurisdiction over hospital staff disputes have seen staff exclusions as improper private usurpations of state licensing functions, and have viewed hospital staffs which exclude duly licensed physicians as combinations in restraint of trade. Seck-

39. One example is the treatment of a mental patient whose symptoms include hatred or fear of another race or group in a short term psychiatric treatment center in a general hospital or in a mental hospital.

40. The medical staff of a hospital is a voluntary association of physicians permitted by the hospital to practice their art, as independent contractors, using the hospital's facilities.

41. Artificial kidneys, electroencephalographic and X-ray equipment and substantial supplies of whole blood and various parental solutions are examples of the modern therapeutic tools which only hospitals can maintain.

42. Among other considerations militating against such an attempt are its possible tax consequences. Cf. Howard v. Commissioner, 39 T.C. 833 (1963).

43. Over 250 of Chicago's approximately 300 Negro physicians are general practitioners. All of the general practitioners are said to have been denied hospital staff appointments, "because hospitals need specialists." Integration: What Is Hospital's Role, Hospitals, Oct. 16, 1963, pp. 20-21.

44. The N.A.A.C.P. has estimated that Cone will affect discriminatory practices in approximately 2,000 medical facilities in 14 southern and "border" states. New York Times, Mar. 26, 1964, p. 16, col. 7.

45. The status of a license to practice as a "right" or a "privilege" is, of course, still unresolved. Cf. Hayman v. Galveston, 273 U.S. 414 (1926); Reich, The Neze Property, 73 YALE L.J. 733, 735, 740 (1964). 
ing to remedy these abuses, courts have applied "freedom of choice of physician" statutes, ${ }^{46}$ broad formulations of public policy, ${ }^{47}$ state anti-trust law ${ }^{48}$ and even section three of the Sherman Act. ${ }^{49}$ This kind of solution, pointing toward judicially-compelled staff admission for all properly licensed physicians, presents a simple and direct method of realizing the goal of non-discrimination. However, it also endangers the quality of medical care, for one of its premises - that state licensing machinery exerts effective control over medical competence - is false. In fact, state licensure requirements, adequate a half-century ago, have been rendered obsolete by the rapid progress of medical knowledge. The field of surgery provides an example. Typical state license statutes to require proof of graduation from an accredited medical school, one year's internship, and successful completion of a basic science examination. When most state statutes were enacted, amputation and simple abdominal operations constituted the bulk of surgical practice, and surgeons rarely had more than one year of training after graduation from medical school.12 Today, surgical procedures involving the stopping of the patient's heart for long periods are routine, and transplantation of vital organs is being attempted with increasing frequency. Most of the training which enables the surgeon to carry out these and other modern procedures is obtained during residency and other postgraduate specialty training ${ }^{52}$ following internship; the completion of medical school is, for the modern surgeon, only the beginning of his course of study. Yet under state statutes any licensed physician may undertake any surgical procedure, even though he has undergone no residency training, and though his entire knowledge of surgical technique may have been gained from three medical school lecture courses and four "clerkship" courses which involved assisting at operations. ${ }^{53}$ Similar gulfs between statutory requirements and

46. Stribling v. Jolley, 253 S.W.2d 519 (M1o. 1952); Albert v. Gogebic County Pub. Hosp., 341 Mich. 344, 67 N.W.2d 244 (1954).

47. Greisman v. Newcomb Hosp., 40 N.J. 389, 192 A.2d 817 (1963).

48. Willis v. Santa Ana Community Hosp. Ass'n, 58 Cal. 2d 806, 376 P.2d 568 (1962).

49. The Group Health Cases, note 6 supra.

50. See e.g., N.J. Rev. Stat. $\$$ 45:9-6 and 9-7 (Supp. 1963), the statute applicd in the Greisman case.

51. Most of these statutes were passed around the turn of the century. Postgraduate internship programs were inaugurated at about the same time. Cope, The Edtcotion of the Doctor, in The Hospital in Contesiporary Life 168 (Faxon ed. 1949).

52. Specialists, particularly surgeons, often spend more years in postgraduate study than in medical school. Cf. Ibid.

53. These are the requirements for graduation of the Yale School of Medicine. Candidates for the MI.D. degree must complete:

Surgery 103, General Surgical Ward and Dispensary Clerkship.

Surgery 104, Orthopedic Ward and Dispensary Clerkship.

Surgery 105, Urologic Ward and Dispensary Clerkship.

Surgery 106, Neurosurgical Ward and Dispensary Clerkship.

Surgery 107, Otolaryngology.

Surgery 108, Ophthalmology.

Surgery 109, Surgical Clinic.

YaLE UNIVERSITY, BuLletin, Series.60, No. 17, 113-16 (Sept. 1, 1964). 
the actual training necessary to carry out complex therapy exist in other areas of medicine. State licensing schemes, instead of requiring the level of skill necessary for many of the more complex areas of modern practice, only call for the kind of training needed for elementary procedures. Staff exclusion is the only prior restraint presently operating to prevent minimally-trained physicians from attempting complex therapy far beyond their level of skill. ${ }^{54}$ Staff rules require a physician to demonstrate a high level of competence before he is allowed to perform complex procedures; they allow for periodic reappointment to the staff to assure that he retains his competence, and provide machinery to allow evaluation of his performance ${ }^{55}$ in order that his competence may be continually judged. Rather than usurping state functions in regulating medicine, staff rules fill a regulatory vacuum; hospital stafis are the only organs which realistically exercise control over medical quality. ${ }^{50}$

Thus, the issue is joined. The court seeking to enforce the staff non-discrimination mandate of Cone must do so in a manner calculated to have the least deletrious effect on the quality of medical care, currently protected by staff selection policies. A number of possible solutions may be suggested : the court might order hospital appointment for all who meet the statutory stand ards, but urge the legislature to enact new licensing laws requiring the high level of competence now required by hospital staff rules; the court might itself apply a new higher standard; it might appoint an impartial expert to administer the nondiscriminatory application of proper competence standards ; it might leave the enforcement of standards to the hospital staff and attempt by some kind of partial review to assure that race is not used as a criterion; or finally, the court might very well effectively abdicate, and content itself with a mere exhortation to the hospital to operate its self-regulatory system without regard to race. Each of these lines of attack must be evaluated in terms

54. Speaking of the other restraints on the quality of practice, both prior and subsequent, Dr. Albert W. Snoke, former president of the American Hospital Association, has written:

If a physician was doing inadequate surgery in a community, what actual power or influence towards either preventing him, correcting him, or controlling him exists in the county medical society, the state medical society, the AMA, the specialty boards in surgery or subspecialties, the various societies or colleges in surgery or its subspecialties, or organizations like the American College of Surgeons (?)

The answer is that if that surgeon or pseudo-surgeon wishes to continue as he has in the past and possesses a license to practice medicine and surgery in the state ... he can do whatever he pleases within the limitations of his conscience or the gullibility of his patients. He really has to be terrible or crooked before any of these bodies will even do anything more than to regard him with horror. This includes the State Board of Medical Examiners or the State Department of Health.

Letter, Dec. 16, 1963, on file in Yale Law Library.

55. See, e.g., Grace-New Haven Connunity Hospital By-laws for the Medical StAFF, March 1, 1960 (revised Nov. 28, 1962) [hereinafter cited as Grace-New Haven By-lazes]; and American Hospital Association, Model Medical Staff By-lazes, Rulles and Regulations, Hospital Accreditation ReFERENCEs (rev. 1961) [hereinafter cited as Model By-laws].

56. Letter from Dr. Albert W. Snoke, supra note 54. 
of its efficacy in enforcing the mandate of Cone, and in allowing maintenance of the highest practical standard of care as compared to the present medical staff procedure.

The goal of present staff procedure is to delineate exactly the competence of each member-physician and the medical and surgical procedures he shall have the privilege of carrying out. The device adopted to this end is division of medical practice into a number of specialty areas, ${ }^{57}$ within each of which a hierarchy of competence is created. ${ }^{58}$ Each member of the staff occupies one or more of the specific pigeonholes within this system and must be periodically reappointed to it. ${ }^{59}$ Appointment is by the hospital governing board, on the recommendation of physicians at the top of the hierarchy within each specialty department, acting either in the capacity of department heads ${ }^{60}$ or as members of one of the operating committees of the staff. ${ }^{01}$ In the case of refusal to reappoint or demotion in the hierarchy, bylaws often contain provisions for hearing ${ }^{62}$ and appeal to a committee of the hospital board. ${ }^{33}$ In addition to the erection of the hierarchy of competence, staff devices for policing carequality include credentials, medical records and tissue committees, necropsy conferences and consultation requirements, some of which have informal sanctions less severe than demotion in the hierarchy os and all of which serve as sources of information regarding the performance of a particular physician to supplement that which his superiors in the hierarchy gain by day-to-day observation. ${ }^{65}$ On the basis of these data, the performance of each member of

57. In a small hospital, the division can be simply one between medicine and surgery. In a large one, as many as ten full departments, each with various autonomous and semiautonomous subdepartments may be created. Cf. Grace-New Haven By-lou's, Art. VI.

58. See, e.g., recommended division into honorary, consulting, active, associate and courtesy staff members. Model By-laws, Art. IV, §§ 2-6.

59. The usual period is one year. See, e.g., DIodel By-lows, Art. III, § 3.

60. See Grace-New Haverz By-laws, Art. IV, § 4(B).

61. Only the credentials committee is specifically mentioned in the appointments seetion of the Model By-laws, Art. III, $\S 4(5)$, but other policing committees, such as medical records and tissues, are required to submit periodic reports to the exccutive committee, which would, if they had bearing on appointment or reappointment, submit them to the medical staff as a whole, which in turn must approve the department head and credentials committee recommendations (Model By-law's, Art. III, $\S 3(1)$ ) to the hospital governing board.

62. Model By-laws, Art. III, $\$ 5$.

63. Grace-New Haven By-laws, Art. IV, \& 4(C).

64. Credentials committees evaluate the qualifications of physicians applying for staff appointment; medical records committees insure that proper records are kept of the course of each patient's treatment (including any data which might demonstrate negligence or bad judgment of the physician); tissue committees compare pathology reports on operatively removed tissue with preoperative diagnoses; necropsy conferences are informal departmental inquiries convened when a patient dies in the course of treatment; consultation requirements are staff rules making mandatory a check on diagnosis by a second qualified physician before certain dangerous procedures are carried out.

65. Cf. Model By-laws, Art. VI, $\S 2(2)$ : "[P]rivileges shall be based upon an applicant's training, experience, and demonstrated competence which shall be cvaluated by review of the applicant's credentials, direct observation by the active medical staff, and review of reports of the Medical Records and Tissue Committees. ...." 
the staff is continually evaluated, and his position in the hierarchy changed if necessary. The number of steps ${ }^{66}$ available within the hierarchy in all but the smallest hospitals makes it possible with some exactitude to place a physician at a level which corresponds to his qualifications. And in the case of the erring physician, a graduated series of sanctions, none of which extends to complete delicensure ${ }^{67}$ assures that no misdeed will go unpunished for lack of an appropriate disciplinary measure.

Incentive for scrupulous enforcement of this regulatory scheme by the medical staff on its own members is provided by the Joint Commission on Accreditation of Hospitals (JCAH) ${ }^{68}$ which pays careful attention to medical staff structure, standards and rule enforcement when accrediting an institution, and which can work economic hardship on a hospital hy refusing accreditation. ${ }^{\text {ol }}$ In practice, the actual levels of competence required for each particular step in the hierarchy at a given hospital tend to rise under JCAH pressurc as far as is consistent with the quality of medical personnel available in a given area. ${ }^{70}$ These levels therefore tend to respond both to general improvements in the quality of medical education, and to such local increases in medical expertise as result from acquisition of new therapeutic tools, acceptance of

66. See note 58 supra.

67. Sanctions range from informal private reproof of a superior through formal reprimand, demotion by one or more levels in the hierarchy, to expulsion from the medical staff. The flexibility of this system allows it to be applied in whatever measure appropriate. Accordingly, staff sanctions are available for relatively minor transgressions, and are not confined (as are formal state delicensure proceedings and the rough justice of tort remedy) largely to the criminal or grossly negligent physician. In contrast to the informality of medical staff proceedings, grievance committees of local medical societies are encouraged to give such due process protections as the presumption of innocence, the right to counsel, the right to appeal, the right to cross examine, and the right not to be convicted of any offense not contained in the formal statement of charges. See, Model By-m laws (for Grievance Committees), in Medical Disctplinary Committee of the AMA, Report to the Board of Trustees, Appendix 4, June 1961.

68. The JCAH is an organization sponsored by the American College of Surgcons, the American College of Physicians, The American Hospital Association and the American Medical Association. It is, however, an autonomous corporation. See By-lanes of the jCAH, American Hospital Association, Hospital Accreditation References (rev. ed. 1961).

69. Refusal of accreditation automatically withdraws recognition of internship and residency training administered by that hospital. This seriously curtails the hospital's ability to secure the very cheap expert services of such trainees.

70. An example may be seen in varying hospital practice as far as allowing gencral practitioners to conduct surgical operations is concerned. GP's are generally barrce from surgery in large and middle-sized hospitals, but are still widely allowed to conduct operations in smaller hospitals serving areas with a relative shortage of board or college certified surgeons. Cf. Hendryx, It's Time GP's Dropped Surgeryl, Medical Economics, Nov. 5 , 1962, p. 118. A considerable number of litigated staff membership cases have arisen when a general practitioner formerly allowed to perform operations is excluded so that the hospital may retain or attain JCAH accreditation. See, e.g., Hughes v. Good Samaritan Hosp., 289 Ky. 123, 158 S.W.2d 159 (1942); Edson v. Grifin Hosp., 21 Conn. 55 (Supp. 1958). 
research contracts or increase in hospital size. ${ }^{71}$ As might be expected, because of these possibilities for change in hierarchy standards, the standards tend to be vaguely spelled out in medical staff bylaws, if they are spelled out at all. ${ }^{72}$ This vagueness stems not merely from the possibility of change, but also from the conscious intent of draftsmen seeking to allow the widest possible discretion in the weighing of any particular physician's qualifications. The JCAH urges hospitals to enact bylaws allowing those considering the granting or withholding of privileges from a physician to take into account personal factors difficult to allow for in standards of general application. ${ }^{73}$

If it be granted that the protection of care quality is an important enough interest to require that any error through inexactness in the system fall on the side of better standards, rather than fairness to the particular physician, the JCAH position is certainly a correct one. The prevalence of team practice $^{74}$ in the most complex areas of medicine and the closeness with which team-members operate suggest that the ability of a physician to work harmoniously with other team-members be weighed when he seeks to enter such an area. In other contexts, the quality of care would be best served not by promoting a staff-member on the basis of his formal training alone, but also by consideration of such personal factors as how he responds to emergency and responsibility, how well such almost unmeasurable qualities as his diagnostic intuition and surgical "nerve" meet the requirements of the position he seeks, and how well he "relates" to patients and his fellows. Similarly, in cases involving demotion or discharge of a physician from the staff, if first considerations are for care quality, the staff should be able - without conforming to judicially prescribed standards of due process - to demote or discharge the doctor who has a previous history of wrongdoing, ${ }^{75}$ or who gives his colleagues a general impression of incompetence, or who has had his judgment or skill affected by poor health or advancing age, ${ }^{78}$ or who is temperamentally unstable to a degree that it affects the quality of his work or the successful functioning and morale of other staff members.

71. The effect of improved hospital facilities in attracting higher quality physicians to an area was cited as an argument for the passage of the Hospital Survey and Construction Act by a spokesman for the state which will be the first to feel the effects of Cone. See quotation from the testimony of Dr. Carl V. Reynolds, State Health Officer of North Carolina, S. Rep. No. 674, 79th Cong., 1st Sess. 4 (1945).

72. See, e.g., Model By-laws, Art. VI, § 2.

73. See American Hospital Association, Hospital Accrenttation Refereices 112-14 (rev. ed. 1961).

74. This phrase, not a medical term of art, is here used to describe the informal formation of teams of practitioners to carry out complex therapeutic procedures within a given hospital.

75. As in Wyatt v. Tahoe Forest Hosp. Dist., 174 Cal. App. 2d 709, 345 P.2d 93 (1959).

76. Cf. Amirpican Hospital Association, Hospital Accreditation Referseices 113 (rev. ed. 196i). 
This broad discretion, as efficient a device as it can be in protecting the quality of care, can be, of course, equally efficient in excluding Negroes or other minority groups from hospital staffs, ${ }^{77}$ and there is no doubt it is sometimes so used, despite JCAH adjurations against such use. ${ }^{78}$ Perhaps the simplest alternative open to the court is simply to order admission of plaintiff physicians and leave to the legislature future regulation of the quality of care. Even assuming the legislature met this challenge, there probably would still be adverse consequences to care quality. Even were the statutory scheme to incorporate the hospital staff's hierarchical structure and provide for a variety of limited term licenses based on competence in each specialty area, it still might lack the flexibility necessary to deal with the constantly increasing complexity of medical practice. ${ }^{78}$

Alternatively - although it seems unlikely - the court might itself assume the burden of developing higher standards and applying them as cases come

77. See note 43 supra.

78. Harrison, Control of Medical Staff Apfointments in Voluntaki NonPROFIT Hospitals 25 (1963).

79. Probably the most appropriate form of statute would set forth broadly-phirased standards and provide for the creation of an administrative agency to isstue regulations setting up the hierarchy and the appropriate level of competence for each. Perhaps the closest existing analogue to such a structure is federal legislation governing amateur radio transmission. Under the authority and within the broad guidelines of the Communications Act of 1934 (47 U.S.C.), the Federal Communications Commission has erected a licensure hierarchy according to which radio amateurs are graded as to competence and according to which they are granted the right to transmit radio signals of various power levels, and on various frequency bands. 1964 THE RAdro AMATEur's HANDBOoK 11-14. Licenses are issued for a limited time only, and the act provides that they confer no property rights in the holder. 48 Stat. 1081 (1934), 47 U.S.C. $\$ 301$ (1958). The commission has the power to determine frequency assignments. 48 Stat. 1082 (1934), 47 U.S.C. § 303c (1958). Or it may suspend or amend any license. 48 Stat. 1082 (1934), 47 U.S.C. $\S \S 303(\mathrm{~m})$ \& (f) (1958). Despite the flexibility of the commission's power evident on the face of the statute, regulations governing amateur operation have becn allowed to become relatively inflexible. The original allocation of frequency bands gave amateurs the region of the spectrum below 200 meters in wave-length. Act of Aug. 13, 1912, ch. 287, 37 Stat. 302. These wave lengths were then thought useless. 1964 RADro AMrATEUR's HANDBOOK 7. Later discovery that they are instead the most valuable for longdistance transmission did not keep amateurs from retaining substantial portions of this band for their use. Id. at 13. While the nature of electromagnetic communication has changed even more radically than the nature of medicine in recent years the atmatcur operator hierarchy and the approximate levels of competence required for cach step have remained generally stable. A proposed plan for raising competence standards for some steps of the hierarchy has brought widespread opposition by amateur operators (sce, c.g., letters in Correspondence from Members, QST, Nov. 1963, p. 83) even though the clingo may be necessary to prevent substantial curtailment of amateur operation in the long run. QST, Oct. 1963, p. 48 . This perhaps suggests that an agency charged with regulating hospital staff appointments might find itself similarly pressured to maintain the status quo by physicians and organizations of physicians. The JCAH, which presently imposes hierarchical standards on hospitals is effectively insulated from such pressures by the fact that its immediate constituency is not composed of individual physicians, but of four national organizations of hospitals and physicians. 
before it. But even if the court succeeded in acquiring the considerable amount of expertise necessary, problems would remain. Courts are institutionally committed to modes of thought which could seriously affect care quality; preoccupation with due process could easily result in overly considerate treatment of the erring or negligent physician, ${ }^{80}$ and the judicial tendency to allow the rule of a particular case to harden into a doctrine of law ${ }^{81}$ could result in the establishment of a set of criteria for competence which although proper for the time and place where first applied, might eventually become as outdated as present licensing statutes. Nor would the delegation of the task of setting standards to an impartial expert provide a viable solution. Such an expert, granted his appointment was procedurally and practically feasible, ${ }^{82}$ might be unencumbered by inappropriate judicial attitudes, but he would still face certain of the other difficulties which would confront a court. Both would find it hard to judge accurately the standards of competence appropriate to a particular hospital, and both would find it difficult to obtain the kind of observational and "demeanor" evidence a medical staff may gather by watching the day-to-day performance of a practitioner ${ }^{83}$ Moreover, the expert, himself a physician, ${ }^{84}$ might have certain peculiar disabilities. There are in all branches of medicine legitimately competing approaches and therapies for many diseases and conditions, and the expert might unfairly deal with a medical staff whose

80. Cf. Wyatt v. Tahoe Forest Hosp. Dist, 174 Cal. App. 2d 709, 345 P.2d 93 (1954).

81. This "tendency," which is no more than the doctrine of stare decisis under another name, cannot be condemned. It is the main tool which a court has to cnable it to move along the continuum between "fact" and "law." However, in any situation in which the "legal" principle to be served is vague and formless (e.g., "good medical care," or exclusion of "coerced confessions") and there are a multiplicity of factual elements to be considered, this tool loses its edge and the court is faced with a choice of (a) preserving the rule by inventing exceptions to it and eventually producing a meaningless labyrinth or (b) deciding the issue on a case-to-case basis. The first alternative is hardly desirable in any case; the second, although it may work fairly well in some areas, such as coerced confession [e.g., Culombe v. Connecticut, 367 U.S. $56 S$ (1961)] would be somewhat clumsy' if applied to Cone-type cases. Only the Supreme Court is competent to try cases on "the totality of circumstances," and since this technique invites, rather than discourages litigation, the Court is wise to reserve it for hard constitutional questions. The constitutional question in the area of medical staff appointments is settled by Cone, and while requiring the Court to weigh every medical staff admission case would prevent the formulation of a too-rigid "rule," it would also add a constitutionally unnecessary burden to the Court's docket. The Court has, on occasion, chosen to abandon all "rules" and decide non-constitutional questions on a case by case basis [cf. FPC v. Hope Natural Gas, 320 U.S. 591 (1944)] but the wisdom of this practice is not thereby established.

82. There appears no reason why the court could not appoint a master in such situations. FED. R. CIv. P. 53. There might be difficulty in some parts of the country, however, securing an expert conversant with hospital and medical affairs who is sympathetic to the goals of Cone.

83. See note 65 supra.

84. It would seem pointless to shift responsibility to a master unless the master were better situated to consider the factual elements than the judge. The only persons so situated would be physicians or hospital administrators, who often hold A1.D. degrees. 
disaffection with the plaintiff-physician was not racial, but theoretical in origin. It may be suggested that both care quality and the progress of medical research are best served by allowing hospitals to commit themselves to one of the available theories of treatment and to select staff members in accordance with this commitment. $^{85}$

Since the medical staff seems to be the only agency able to bring the advantages of experience and knowledge to the definition and application of medical standards, it may be suggested that the court seeking to enforce non-discrimination would be best advised to treat the staff almost as if it were an administrative agency, ceding to it the judgment of competence and attempting to prevent the use of race as a criterion through some form of review. The problem then becomes one of finding a form of review which best serves the goals of both non-discrimination and care quality. The simplest review proceeding would involve only ascertaining whether the staff bylaws included a formal or informal discriminatory proviso. If stuch it provision were included, the court could strike it down as unconstitutional and order the applicant's competence considered without regard to his race. This is the form which review has assumed in a number of other hospital staff cases, ${ }^{86}$ and it is the form which may well commend itself to the district court in Cone. ${ }^{87}$ There is no danger that care quality would be compromised by this action, and it is probable that such a method would meet with the approval of most hospital staffs and administrators. ${ }^{88}$ However, the wide discretion enjoyed by hospital staffs would enable them to evade the order; experience in other areas has demonstrated the ineffectiveness of merely hortatory judicial attempts to control the mental process of administrative tribunals. ${ }^{89}$

Cone's mandate could be far better enforced, it might be argued, if the review of staff decisions were made on the model of trial dc novo. In such a proceeding, the court would require all evidence gathered by the staff, including other doctors' observations of the plaintiff-physician, to be placed on the record before it, and would take further evidence regarding the particular level of competence required for the particular staff appointment in the hospital involved. It could then decide whether, apart from his race, the plaintiff met the hospital's standards, and, if he did, it could order him admitted or reinstated.

85. Both the effective administration of a therapeutic program and reliable craluation of its medical validity could be made exceedingly difficult if a portion of the program had to be entrusted to a staff-member who sincerely believed it to be wrong.

86. This is the New Jersey court's approach. See note 1 supra.

87. As of Sept. 1, 1964, no order had been entered. Communication from Office of the Clerk, United States District Court for the Middle District of North Carolina.

88. Except for its application to portions of a hospital complex not themselves constructed with federal aid, such an order would go little further than the repeal of the $\$ 291$ (f) proviso favored by the American Hospital Association. Hospitals, Sept. 16, 1963, p. 95.

89. See, e.g., the Biscayne cases, gathered in Jafre \& Nathanson, Cases on AdMINISTRATIVE LAW 371-82 (1961). 
Here, again, a recalcitrant staff could probably frustrate the court by rejecting an applicant on the basis of imagined or distorted evidence, but the fact that this would require a conspiracy to commit perjury on the part of high-level staff members makes it seem unlikely. The real difficulty with this form of review lies elsewhere. Physicians are extremely reluctant to discuss openly the errors and misdeeds of fellow practitioners; indeed, to do so may be considered unethical. ${ }^{90}$ To present a staff considering disciplinary action against a member with the possibility that the grounds for such action might one day become public would be to insure that no action would be taken except in the most flagrant cases of abuse. Thus the tendency would be to suppress personal and observational evidence ${ }^{31}$ of misdeeds. The possibility of $d c$ noz'o judicial review of staff discipline decisions would therefore destroy the flexibility which enables that discipline to operate against minor as well as major infractions of standards of good practice, and some improper behavior now penalized would go unpunished. Moreover, even if this difficulty could be avoided, ${ }^{02}$ a further danger to care quality might still be presented by inappropriate judicial reluctance to give proper weight to personal evidence. ${ }^{03}$ Both of the problems presented by this more searching form of review stem from attitudes toward the personal and observational evidence involved. It seems, therefore, that the de novo review would be practical only if, without compromising the quality of care, the evidence adduced before the court could be limited to such impersonal and readily obtainable data as (for the applicant) school grades,

90. While proseription of such behavior is not contained in formal codes of ethics, it is nevertheless considered improper:

Governing all these relationships [between physicians] is the fundamental need of the profession to present a united front. No body of men is more criticized than doctors: we must not foster that criticism by criticizing each other - at any rate we must not let it be known that we do so.

Ogilvie, The Doctor's Relationship to his Professional Colleagues, Mredical Etmics (1957).

91. "Observational evidence" is used here to denote knowledge of medical negligence or wrongdoing gained by other physicians who, working side by side with the erring practitioner, have a chance to observe him in action. Such evidence, of course not hearsay, would be admissible in any court to demonstrate that the errant act was in fact committed, or rather, that the testifier believes he saw it committed. The category of "personal evidence" is here used in an effort to allow for some of the basically imponderable aspects of medical practice, such as the intuitive act of diagnosis or the ability of a good surgeon to act quickly and surely in dealing with a sudden emergency on the operating table. "Personal evidence" is thus used to denote the kind of evidence which could be given by" another practitioner who observed the erring physician make a medically justifiable but wrong choice in a diagnostic situation or surgical emergency, when a better practitioner, presented with the same circumstances, would have made the correct decision. Such evidence would be vital in deciding whether to give the erring doctor a position of great responsibility in the hierarchy, but would of course be almost surely discredited by vigorous cross-examination, especially if standard treatises were used to impeach the witness.

92. E.g., by taking the evidence in camera.

93. See note 91 supra. 
proof of postgraduate training and recommendations from teachers and superiors and (for the hospital) statements of the amount of formal training required for a given appointment. But, as has been suggested, ${ }^{94}$ the effect on care of such a limitation of evidence could, in some circumstances, be quite serious.

However, examination of the kinds of decisions medical staffs make in different contexts and at different hierarchical levels suggests that personal and observational evidence are not of equal importance in every staff judgment. The great responsibility entrusted to the specialist at the top of the hierarchy and the necessarily intimate team practice in which he must often engage demand that personal and observational data be weighed in considering his case. They are perhaps not so crucial, however, in testing the basic intelligence and general medical knowledge required of a physician performing the much less dangerous procedures at the bottom of the hierarchy. Further, while data gained from personal observation of a physician's performance may be carefully considered in deciding questions of discharge, demotion or even promotion, it is often not considered in weighing admission to the staff, simply because of its unavailability. ${ }^{95}$ This suggests that a court attempting to enforce non-discrimination may, with some confidence that it is not endangering the quality of care, review - on the basis of impersonal evidence of professional training and competence - staff exclusions of Negro physicians when such exclusions involve refusals to admit the plaintiff to the lower levels of the hierarchy. It also suggests that as staff decisions shift from contexts involving admission to those involving promotion, demotion and expulsion, and as they involve higher levels in the hierarchy, the court should feel more reluctant to review and reverse them on impersonal evidence, and instead should rely increasingly on the device of remand with a hortatory adjuration to disregard race. It is is difficult to enunciate an easily-manageable standard by which the court could decide when a particular staff decision is so based on personal and observational evidence that summary reversal would be improper. Perhaps the best guidelines for decision in the hard case would be provided by a careful assessment of the amount of such evidence actually available to the staff in making the decision, and the degree of competence required for the staff position in question in relation to requirements for the rest of the hierarchy. In practice, since a large majority of Cone-type cases will probably be brought by physicians denied admission to the lowest level of the hierarchy, ${ }^{00}$ this more

94. See text accompanying note 76 supra.

95. If the applicant has never been on the staff, its members have in all probability (barring his membership in another medical staff to which they also belong) never had a chance to observe him and thus to gain personal or observational evidence of his competence.

96. Negroes are the only minority group effectively barred from hospital medical staffs in the United States, and the majority of Negro physicians tend to be gencral practitioners. See note 43 supra. As general practitioners, at all but the smallest hospitals they are qualified to enter only the lower hierarchical levels. 
difficult problem may not arise for some time. In addition, there are indications that once Negro physicians are granted access to the hierarchy, their promotion may not be seriously inhibited by discriminatory attitudes..$^{97}$

A problem more likely to materialize is expulsion on grounds of incompetence of Negro physicians the court has ordered admitted to the staff. If the action is the result of a sudden raising of the level of formal training required for staff appointment, the court should not automatically conclude that such an upgrading in requirements is mere sham, for standards of competence are sometimes suddenly raised for legitimate reasons. ${ }^{88}$ Instead, the court might consider such factors as whether the change was one required by the JCAH as a condition of continued accreditation, whether the hospital had undergone some major improvement which attracted more qualified physicians to it and whether the new higher standard is in fact being enforced against white physicians at the same hierarchical level. If the staff seeks to justify expulsion on the ground of personal and observational evidence, the court would have no choice but to require that such evidence and additional evidence regarding practices of similarly-ranked white staff members be spread before it, in order that it be enabled to itself decide the justification for expulsion. As has been suggested, this would tend to have some bad effect on care quality. But the effect would be a small one, ${ }^{99}$ and it seems necessary to preclude evasion of non-discrimination orders issued under the mandate of Cone.

97. Research in another area suggests the possibility that white physicians, howerer prejudiced they may be toward Negroes, might tend not to extend this prejudice to Negro physicians with whom they work, regarding such physicians as atypical members of their race against whom discriminatory sanctions need not be applied. See Berg, Ethnic Attitudes and Agreement of White Persons with a Negro Person in the Autokinetic Situation [unpublished doctoral thesis on file in the University of Pennsylvania Library, XXIII Dissertation Abstracts 334 (1961)].

98. See notes $70 \& 71$ supra and accompanying text.

99. Presumably, there would be no reluctance on the part of the staff to offer observatonal evidence in such cases, but the court could still probably decline to give much weight to personal evidence, which is certainly an element in deciding whether to keep a physician on a medical staff. If personal evidence did tend to show error on the part of the physician, and the court, ignoring it, ordered the hospital to retain him on the staff, care quality at such a hospital would ex hypothesi decline. The quantum of this reduction in standards is not likely to be great, however, since the Negro physician is likely to be at a hierarchical level where the kind of intuitive judgment personal evidence goes to is not as important as it is at top levels, and court orders compelling retention of a physician despite the existence of derogatory personal evidence probably would occur only when the physician had previously been ordered admitted to the staff under the Cone doctrine. 